\section{The importance of financial accounting auditing in the identification of economic criminal activities}

Emilia VASILE, Athenaeum University, Bucharest, Romania, E-mail: rector@univath.ro

Petrişor Gruia, Valahia University, Tîrgovişte, Romania, E-mail: gruia.petrisor@yahoo.it

\section{Alistract}

In order to provide favorable premises for preventing and combating economic and financial criminality and developing a healthy business environment, professional accountants have a duty to manifest themselves with increasing responsibility for the satisfaction of professional, ethical and deontological requirements, as well as for the expression of respect and attachment to serve the public interest, defined as "the collective welfare of the community and institutions, served by professionals in accounting." In civilized communities, professional accountants play an important role in society, which is why their responsibility can not be reduced to the satisfaction the individual needs of a customer or state, but it must be reported, primarily to the public interest.

This research paper deals with the role of financial accounting auditing in identifying criminal activities in the economic field. To this end, the objectives of the financial accounting audit, support for the financial accounting system, as well as possible risks, frauds and errors, specific to the financial accounting audit, are presented.

Keywords: Financial, economic, government policy; regulatory policies.

\section{JEL Classification: M42}

To cite this article:

Vasile, E., Gruia, P. (2018), The importance of financial accounting auditing in the identification of economic criminal activities, Audit Financiar, vol. XVI, no. 3(151)/2018,

pp. 398-406, DOI: 10.20869/AUDITF/2018/151/019

To link this article:

http://dx.doi.org/10.20869/AUDITF/2018/151/019

Received: 11.05 .2018

Revised: 05.06.2018

Accepted: 11.06.2018 


\section{Introduction}

The audit has been the guarantor of the veracity of the audited financial statements and the insurance factor of the shareholders, potential or existing shareholders, as well as other third parties directly interested in the data published in the financial statements and the state of a company. In order to be able to highlight and assess the extent of the auditor's liability, both in terms of the range of possible sanctions and in terms of the severity of this liability, it is necessary to relate this analysis to the role, responsibility and the way in which the auditor influenced corporate governance worldwide

The objective of an audit of the financial statements is to enable the auditor to express an opinion on the financial statements if they are prepared in all material respects under a financial reporting framework. The terms used for the auditor's opinion - "give a true image" or "present fairly in all material respects" - are equivalent.

In terms of the role of financial audit, it consists of verifying and reviewing financial information having an internal utility (management and management of the entity) and another external, third party information (shareholders, investors, government institutions, clients, suppliers, creditors, bank and others), exercised to protect resources and ensure the credibility of this information.

Information provided by specialists in this area is necessary for all categories of users: managers, shareholders and associates, tax authorities, bankers, trade union organizations that sometimes have conflicting interests. That is why the results of the audit work must be accurate and drawn up on the basis of the legal documents in force. They must ensure the quality and consistency of the accounting system and are designed to ensure fair, honest and complete reflection in the balance sheet and the profit and loss account of the heritage, financial position and results of the year.

The objective of the audit has evolved from the detection of frauds and errors, a process involving a thorough check of all patrimonial transactions and their accounting records, an opinion on the true image of the patrimony, the financial situation and the results obtained by the company. In this regard, the extent to which the information recorded in the accounts reflects the economic events that took place in a given period is pursued and the auditor's efforts are intensified to identify possible manipulations of information provided by the financial system to prevent creative accounting cases; or fraud.

\section{Analysis of the speciality lîterature}

According to the literature (Boulescu, M., et al., 2000), "audit is the process of legally empowered individuals or legal entities, called auditors, that analyze and professionally assess information about a particular entity , using specific techniques and procedures to obtain evidence, called audit evidence, based on which he draws up the audit report and a responsible and independent opinion. "

This implies the use of evaluation criteria resulting from legal regulations or good practice that is unanimously recognized in the field in which the audited entity operates. The audit process is conducted on the basis of national or international standards, the auditors being persons who acquire this quality under the conditions strictly regulated by the legislation in force.

Practically, the audit is a professional reasoning that can be applied in any field of activity (see environmental audit, management audit, quality audit, etc.).

Dobroțeanu, L. and Dobroțeanu, C.L. in the book "Auditing Concepts and Practices, National and International Approach" highlights the fact that the financial audit specifies the coordinates in which the financial auditors are operating, while the profession of financial auditor is the "framework that ensures the conduct of the financial audit process." In order to fulfill the mandate received, by expressing an objective and independent opinion on the compliance of the financial statements with the accountant referenced, under the most significant aspects, the auditor must obtain a series of audit evidence (Chersan, 2012)

The development of world-wide international exchanges with the completion of complex accounting work requiring extensive knowledge 
and analysis to be able to be understood has made it necessary to have a profession and a comprehensive and credible information work to ensure the collaborators that the economicfinancial indicators prove the patrimony reality. Thus, the profession of financial auditor appeared, whose specific work is the financial audit report.

At the same time, Arens A. and Loebbecke K. in "Audit: An Integrated Approach" asserted that "The audit consists in collecting and evaluating information evidence in order to determine and report the degree of compliance of that information with a set of predetermined criteria . The audit should be performed by a competent and independent person."

\section{Methodology of research}

In order to highlight the importance of the financial and accounting audit in the identification of criminal activities in the economic field, we have analyzed a series of specialized papers dealing with the subject. The research methodology used is the fundamental type of data analysis and previous research in the literature.

In our research, we supported the three structuring principles of a research:

- research can only be reached if this process is concerned with a limited objective, circumscribed for a situation of knowledge and social demand at a given moment;

- defining a specific problem, representative of the willingness to demonstrate, contributing to a set of issues in the field of research under consideration;

- A pertinent methodology allows to access, record and analyze situations from representations and observations.

\section{The objectives of the financial-accounting audit and the evidence collection techniques}

The accounting information system, due to its functions, is the main source of information for financial and accounting auditing and at the same time it is one of its main objectives.
Regardless of the methods, means and techniques used for data processing, the audit has the task of pursuing two target groups 1 :

1. the reality, sincerity and integrity of the information provided by the economic records;

2. the legality, necessity and economy of the recorded economic and financial operations, as well as the integrity of the patrimony of the economic agent or of the respective public institution;

By following these two sets of objectives, the financial-accounting audit may be confronted with the following situations:

(a) the accounting documents and records are properly drawn up, kept up to date and comply with the requirements of the law and the decisions of the boards of directors and comprise only actual, factual and accurate transactions;

(b) the irregularities found in the preparation, movement and processing of documents and in the keeping of accounting registers are only of a formal nature, such as: the documents contain inaccurate corrections, the records are not kept up to date, correspondence between the accounts is not complied with, from operative bookkeeping, analytical accounting and synthetic accounting, etc.

(c) irregularities in the organization and management of accounting determine, favors or masks cases of poor management, tax evasion, evasion, distortion of results, etc.

Documentary verification identifies the nature of the deficiencies (form or substance) and measures are taken to prevent and eliminate them and / or to sanction the culprits, as the case may be.

In order to express its opinion on the assurance of the fair image through the financial statements, the auditor is required to ensure that the following criteria and objectives have been met:

The criterion of completeness and integrity of records (completeness). This criterion requires that all

1 Munteanu V., Zuca M., Zuca Ş., (2005) - Control and Financial-Accounting Audit, Ed. Universul Juridic, Bucharest

2 Feleagă L., Feleagă N. (2007) - Financial Accounting - A European and International Approach, Economic Publishing House 
transactions occurring in an enterprise be reflected in appropriate supporting documents and recorded in the accounts without omission and without some accounting for them several times.

Criterion of recordings. All the information contained in the annual accounts must be justifiable and verifiable. Then all patrimonial items reflected in the accounting must be consistent with those identified physically by inventory or other processes (third-party confirmations, laboratory tests, etc.). Revenues and expenses, as well as the assets and liabilities presented in the annual accounts, must be real and concern the enterprise.

The criterion of correct bookkeeping and correct presentation through annual accounts implies respecting the principle of exercise independence. As a result, operations must be recorded in the appropriate periods, and through the regularization work, the correct delimitation over the period of expenditure and revenue management is ensured by: provisioning, reversal of provisions, distribution of price differences over expenses and inventories, exchange rate differences related to foreign currency denominated assets, translation differences related to foreign currency receivables and liabilities, prepaid expenses and accrued income that are "recorded" in the balance sheet, etc. ${ }^{1 .}$

A fair assessment makes all property items and all economic and financial operations evaluated in accordance with the accounting rules and principles. Also, all the calculations underlying the records in the accounting must be correct. All economic and financial operations should be recorded in the appropriate accounts with respect to the correspondence between the accounts established by the rules for the implementation of the chart of accounts. Failure to comply with these correspondences may help to mask fraud, unlawful compensation, distortion of balance sheet items or indicators such as assets, stocks, expenses, results of the exercise, tax liabilities, turnover, etc.

\footnotetext{
1 Olteanu I., Bistriceanu G. (2005), Tax evasion. Methods and Techniques to Combat Tax Evasion, ASE Publishing House, Bucharest
}

\section{Rïsks, frauds and possible errors, specific to financial-accounting audit}

The specialized literature reveals that the amount of audit evidence required to prove compliance with a given assessment criterion is always commensurate with the risk that the auditor would give an opinion on compliance with the criterion, but in reality there is a strong departure from (deletion) to that criterion, which will be covered by the importance for users of the audit report. The risk in question is called global audit risk.

Therefore, the audit can not provide absolute certainty, but it is necessary to limit to a low and acceptable level the overall audit risk, ie the auditor's ability to formulate an inaccurate opinion or conclusion in an audit report. In this regard, it will be taken into account that in its turn the opinion of the audit will be inaccurate and misleading its user ${ }^{2}$.

Since it is not practical to recover all operations in a set of financial statements, the auditor must accept a certain level of overall audit risk.

NOTE: Given the expectations of users of financial statements made by public bodies, especially with regard to legality and regularity, only very low levels of overall audit risk are used and recommended, $1-2 \%$.

a) Inherent or critical risk is generally the risk of material (material) misstatement or of erroneous statements independently. Inherent risk in fact amounts to the possibility that a balance of an account or a category of financial operations may contain erroneous information that could be individually significant or when it is aggregated with erroneous information from other balances or

2 An audit report misleads if: the report mistakenly states that there was a non-compliance with the evaluation criteria. For example, it is stated that financial statements are misleading when, in reality, this is not the case or it is stated that the entity's management has not made every effort to achieve the objectives; when, in reality, the objectives have been achieved, achieved; omitted by report the indication of the limits of the scope of the audit and that it may influence the interpretation of the results 
financial transactions as a result of the absence of effective internal controls.

The inherent risk depends on the nature of the entity under audit, the work it carries out, and the susceptibility of activity-related errors.

In order to estimate the inherent risk, the auditor performs an assessment of the environment (context) in which the entity operates and an assessment of the characteristics of the issue being audited.

b) The risk of control is the risk that the accounting and internal control systems of the audited subject do not prevent or detect in a timely manner a misstatement or an affirmation that could materially materialize either individually or together with errors in other balances or categories of operations.

As the control risks persist due to the inherent limitations of the accounting and internal control systems, the auditor performs the assessment of the effectiveness of the entity's internal accounting and control system on the prevention and detection of significant (material) errors.

The control risk assessment is carried out in depth at the level of each balance of the accounts or the category of financial operation and two situations can be recorded:

- The auditor finds that the accounting and internal control systems are not functioning effectively and effectively, in which case the control risk is at a high level;

- The auditor identifies internal accounting and control systems as effective, capable of preventing, detecting and correcting material misstatement, in which case the control risk is lower;

In order to understand and evaluate the control risk, the auditors carry out a documentation of the accounting and internal control systems, the form and extent of which depends on the size and complexity of the audited subject, and on the nature and structure of the internal accounting and control systems.

c) The risk of non-detection is generally the risk that material misstatement or significant inaccuracy that is not corrected by internal control is not detected by the auditor. Practically, the risk of non-detection is the risk that the underlying procedures used by the auditor do not detect any erroneous information that exists in the account balances or in a financial transaction that may be material (individually or collectively) with other erroneous information from other accounts or transactions.

The more the auditor performs multiple background procedures, the more likely he is to detect any material (significant) error or irregularities in the audited financial statements, and the risk of nondetection is less.

Carrying out the risk analysis is important because depending on the risks of the audit the working procedures are chosen, the scope of the procedures, tests and surveys and the succession date of their application are determined.

From the point of view of the possibility of the risk, there are potential risks and possible risks ${ }^{1}$ :

- Potential risks are most likely to occur if there is no effective control that prevents, discovers and corrects them. These are recorded at the level of all economic entities.

- Possible risks are that part of the potential risks for which management has not taken effective measures to limit them. As a result, there is a strong likelihood that errors occur without being detected and corrected.

From the point of view of the specific nature of the audited entity, the nature of its operations, the functioning of the systems and procedures and significant areas identified by the auditors, the most important risks are ${ }^{2}$ :

A. General risks specific to the entity. These risks arise from their own characteristics to the entity and refer to:

- The risks related to the economic situation of the enterprise. The economic situation of the enterprise differs according to the existence of financial difficulties ${ }^{3}$;

1 Munteanu V., Zuca M., Zuca Ş., (2005) - Control and Financial-Accounting Audit, Ed. Universul Juridic, Bucharest 2 M. Boulescu, op. cit., pp. 43-45

3 If an enterprise has a healthy financial situation without difficulty, management is tempted to pursue a conservative policy and neglect certain business or management functions (including control). If the enterprise is in financial 


\section{- The risks related to the organization's overall organization are determined by several factors, among which:}

- Risks related to the nature and complexity of structures and rules. The more complex these rules, the higher the risk of error. For example, the risk of error in assessing ongoing production in long-life products is higher than in the valuation of commercial stocks;

- Risks related to the quality of management. Good resource management, quality decision-making, high performance management leads to a reduction in risk;

- risks related to the accounting system and internal control system. The system of drawing up primary documents, processing, sequencing data, obtaining annual balance sheets and accounts (execution or profit and loss) should be designed to ensure that any errors are prevented, detected and corrected. Well-designed and applied internal accounting and control systems are an effective means of protecting against the risk of errors:

\section{- Risks related to the absence of} procedures. The existence of clear procedures, separation of service duties, nonadmission of the same person's cumulation of functions is an important prerequisite for risk reduction;

- Risks related to management's attitude. Management attitude in general can contribute to limiting or increasing risks. Auditors consider the management's reaction to the identified risks. This reaction can go from ignoring the risks (those with low probability and low impact) to the use of internal control procedures detailed to prevent and mitigate other categories of risk.

We need to point out that the risks increase when the managers put pressure on the employees, asking them to mask certain situations against shareholders, banks, tax bodies, etc.

difficulty, management may have uncontrollable, dangerous reactions, being tempted to carry out illicit operations, resort to very high interest loans, or postponing good decisions due to lack of financial means.
$B$. Risks related to the nature of the transactions being treated. In the accounting, the existing data can be 1 :

- Repetitive data, resulting from the usual activity of the economic agent (purchases, sales, production, salaries), according to the accounting system practiced, are processed and registered in a uniform manner. For these data, the risk of errors is determined by the quality and reliability of the accounting system;

- Point-specific data that are complementary to repetitive but which are reflected in more or less regular time intervals (eg data from annual inventories or from end-of-year assessments, depreciation data, provisions, allocation coefficients, conversion differences, etc.).

- These data may be risk-taking if their collection is not organized in a reliable manner (the principle of the method's permanence).

- The auditor should analyze them to determine what tests will be applied to them; exceptional data that occur in exceptional operations (mergers, liquidations, revaluations, etc.). For these data, the risk of error or non-detection is greater, especially if the trader does not have sufficiently well-trained staff.

\section{Risks related to the design and operation of} systems. The design of the data collection and processing system should be designed to enable the prevention, detection and elimination of errors. Reliability and proper functioning of the internal control system will reduce risks.

\section{Risks related to significant processes and areas} chosen by auditors based on their experience and professional training, the procedures chosen by auditors inevitably present a certain level of risk.

Our opinion is that the auditor should plan the audit mission so that, based on the risk factors he / she knows, he / she will focus on possible errors that may have a significant impact on the accounts and operations and on the manner of application of the principles of economy, efficiency and effectiveness in the activity of the audited entity.

\footnotetext{
1 Nicolae Ghinea, loan Brandas, Liviu Popa (2009), Financial
} and fiscal crime, Ed. Durans, Oradea 
The audit should take into account the potential impact of a possible fraud on financial information and consider changes to the audit plan and the use of additional audit procedures. Additional audit procedures used to indicate the existence of a fraud include ${ }^{1}$ :

Evaluation of the effectiveness of the control of prevention or detection of frauds and deviations;

- appreciation of the presumed fraud dimension;

- analytical procedures used to test the existence of fraud;

- the interview technique taken by those suspected of having committed fraud;

The auditor should distinguish between presumed fraud and proven fraud. Suspected fraud is considered to be those circumstances that suggest fraudulent action and that come to the attention of the auditor during an audit. This approach reinforces the principle that only the tribunal or equivalent jurisdiction is empowered to decide whether a particular action or operation is a proven fraud.

The use of additional procedures gives the possibility to confirm or refute suspicion of fraud. Sometimes, however, this refutation or confirmation can not be achieved, and then the possible impact of this uncertainty on financial statements (information) needs to be considered.

In the European Community Regulation ${ }^{2}$, the offense is defined as "any infringement of a provision of Community law which has the effect of prejudicing Community budgets, either by reducing own resources collected directly on behalf of the Community or by undue expenditure."

Another document of the Council of Europe, dated July 26, 1995, states the notion of fraud:

(a) in terms of expenditure, any intentional intentional act or omission relating to:

- the use of false or incorrect or incomplete statements or documents that generate the wrongful or inappropriate retention of funds from the general community budget;

1 Bişa C. (2005), Using tax havens. Between Tax Evasion and Tax Fraud, BMT Publishing House, Bucharest

2 See Ionel Bostan, Community Financial Law, Ed. Universitas, laşi, 2004 (Specific regulations section).
- non-disclosure of information by breaching specific obligations with the same effect;

- using funds for purposes other than those for which they were initially allocated;

(b) in terms of revenue, any intentional act or omission deliberate on:

- the use of false or incorrect or incomplete declarations or documents, resulting in the illegal diminution of the resources of the general Community budget or funds managed by or on its behalf;

- non-disclosure of information by breaching specific obligations with the same effect;

- using for other purposes a legal benefit obtained with the same effect.

The error is defined by the literature as an unintentional mistake, regarding:

- mathematical or accounting mistakes in accounting and records;

- omission or misinterpretation of economic and financial phenomena;

- the misapplication of accounting policies (principles, rules, methods);

Responsibility for the prevention and detection of frauds and errors belongs to the management of the entity, which has the obligation to implement adequate accounting and internal control systems. However, such systems reduce, but do not eliminate the risk of fraud and error.

The auditor is not and can not be held responsible for the prevention of frauds and errors, but the audit may act as a way to prevent / discourage them.

The INTOSAI Auditing Standards provide that "regulatory compliance (financial) audits should also test compliance with applicable laws and regulations. The auditor should design the audit steps and procedures to obtain reasonable assurance of the detection of errors and frauds that could have a direct and material effect on the amounts in the financial statements or on the results of the audit. At the same time, the auditor should be aware of the possibility that the unlawful acts have an indirect and material effect on the financial statements or the results of the audit. " 


\section{The occurrence of frauds and errors}

The main factors influencing the risk of fraud and errors are:

a) deficiencies in the design and operation of internal accounting and control systems, as described in the preceding paragraph. Therefore, the assessment of these systems is of particular importance for the audit;

b) the integrity and competence of the entity's management. The auditor considers a number of conditions that may increase the risk of fraud and error occurring as follows:

- leadership is dominated by a single person or small group, the board of directors or the steering committee operating inefficiently;manifesting major discontinuities in terms of;

- correcting weaknesses in internal controls;

- the rapid pace of change of the important staff in the accounting and financial departments;

- The existence of a significant and prolonged under-dimensioning of the number of staff of the accounting department.

c) unusual pressures within or over the audited entity are also a factor that increases the risk of fraud and error and is manifested by:

- deterioration of the quality of revenues, in the sense of increasing the risks resulting from the increase of the share of credit sales in total sales;

- the existence of a significant profit need to support the market price of its shares as a result of a proposed public offer;
- making significant investments in a field characterized by rapid change;

- dependence of the entity, to a significant extent, on one or several products or customers;

d) making unusual transactions (operations) is a factor that can increase the risk of errors and frauds and is manifested by:

- performing unusual transactions, usually near the end of the year, which have a significant effect on profit;

- performing complex or affiliated transactions;

- make payments for services that are too high in;

- comparison with the respective services;

e) Problems in obtaining sufficient and appropriate audit evidence are factors that increase the risk of fraud or error for which the auditor will pursue:

- Inadequate records, for example: incomplete files, excessive changes in accounts and registers, unregistered operations in accordance with legal procedures; registration of operations without adequate documentation, eg lack of appropriate authorizations, supporting documents, changes on documents, etc .;

- Excessive differences between accounting records and third party confirmations.

We finally see that in the case of a computerized data system, there are also conditions that favor the risk of fraud and error. We consider the inability to obtain information from the files due to lack of documentation on the content of the records or programs, but also the existence of a large number of changes to software programs that are not documented, approved or tested.

\section{BIBLIOGRAPHY}

1. Bişa C., Costea I., Capotă M., Dăncău B. (2005), Utilizarea paradisurilor fiscale între evaziune fiscală legală şi fraudă fiscală, Bucureşti, Editura BMT Publishing House

2. Boulescu, M., ş.a. (2000), Fundamentele auditului, Bucureşti, Editura Didactică şi Pedagogică
3. Feleagă L., Feleagă N. (2007), Contabilitatea financiară - $O$ abordare europeană şi internațională, Bucureşti, Editura Economică

4. Ghinea N., Brandas, I., Popa, I. (2009), Criminalitatea financiar-fiscală, Oradea, Editura Durans 
5. Olteanu I., Bistriceanu G. (2005), Evaziunea fiscală. Metode şi tehnici de combatere a evaziunii fiscale, Bucureşti, Editura ASE

6. Bogdan, A. M. (2017), Auditul financiar, Craiova, Editura Universitaria

7. Munteanu, V., Zuca, M., Țînță, A., Virgil, Ş. (2012), Audit financiar contabil: concepte, metodologie, reglementări, cazuri practice, Bucureşti, Editura Pro Universitaria

8. Chersan, I. C. (2012), Auditul financiar: de la normele naționale la standardele internaționale, laşi, Editura Tehnopress
9. Toma, M. (2012), Inițiere în auditul situațiilor financiare ale unei entități, ed. A IV-a revizuită şi adăugită, Bucureşti, Editura CECCAR

10. Dobroțeanu, L., Dobroțeanu, C.L. (2002), Audit Concepte şi practici, Abordare națională şi internațională, Bucureşti, Editura Economică

11. Arens A., Loebbecke K. (2003), Audit: 0 abordare integrată, Chişinău, Editura Arc, 2003 